Singh et al., Afr J Tradit Complement Altern Med., (2018) 15 (1): 199-215

https://doi.org/10.21010/ajtcam.v15i1.21

\title{
A COMPREHENSIVE REVIEW ON THE GENUS PLUMBAGO WITH FOCUS ON PLUMBAGO AURICULATA (PLUMBAGINACEAE)
}

\author{
Karishma Singh $^{1 *}$, Yougasphree Naidoo ${ }^{2}$, Himansu Baijnath ${ }^{3}$ \\ School of Life Sciences, University of KwaZulu Natal, Westville Campus, Durban, South Africa. \\ *Corresponding Author's Email: k1008.singh@gmail.com
}

\begin{tabular}{|l|}
\hline \multicolumn{1}{|c|}{ Article History } \\
Received: Jun. 01, 2017 \\
Revised Received: Oct. 02, 2017 \\
Accepted: Oct. 02, 2017 \\
Published Online: Dec. 29, 2017 \\
\hline
\end{tabular}

Abstract

Background: The genus Plumbago distributed in warm tropical regions throughout the world is the largest genus in Plumbaginaceae. Medicinal plants are characteristic to the genus Plumbago and are cultivated and utilized worldwide. Plumbago auriculata Lam. is common in South Africa and is often cultivated for its ornamental and medicinal uses throughout the world.

Materials and Methods: A comprehensive review of the genus Plumbago with focus on Plumbago auriculata was carried out and information was gathered using scientific publications, conference proceedings, the internet and books. Articles based on the morphology, pharmacological and medicinal uses of Plumbago auriculata was analysed thoroughly.

Results: Plumbago auriculata plant parts posses a wide range of phytochemicals with plumbagin being the marker compound showing various pharmacological activities. Different plant parts are claimed to be used for the treatment of human and animal ailments, however they do exhibit toxic properties and need to be administered with caution. Salt secreting glands and trichomes are characteristic of Plumbaginaceae.

Conclusion: This study reveals new insights on the genus Plumbago and the potential use of species in the genus as medicinal plants. Plumbago auriculata possess the bioactive compound plumbagin and secondary metabolites, thus, it is of high medicinal importance. P. auriculata is a poorly nor favourite studied species in the genus Plumbago and further research needs to be carried out to explore specific details of the species.

Key words: Plumbago, salt glands, trichomes, pharmacological activities, plumbagin, micropropagation.

\section{Introduction}

Over the years, human health problems have been increasing at an alarming rate and are now becoming life threatening. Conventional medicine used to control health problems is often too expensive and has many side-effects. Therefore, many people have turned to the use of medicinal plants for the control and treatment of health problems. Plant extracts have been used for hundreds of years to cure ailments (Balunas and Kinghorn, 2005). The vast resource of thousands of medicinal plants and their contribution to human health are to be discovered. Exploiting traditional medicine systems has served as a promising approach in an era of increasing demand for drug production and rising costs of western medicine, globally.

It has been reported that many plants naturally produce secondary metabolites, commonly referred to as phytochemicals or biologically active compounds which are essential for plant metabolism but play a great role in the plants' protection mechanism (Ascensao et al., 1997). In addition to plant protection, these bioactive compounds also serve as precursors for the development of natural, environmentally friendly and low toxicity pharmaceuticals, flavourants, fragrances, cosmetics and pesticides due to their therapeutic and aromatic properties. Bioactive compounds are either produced, excreted or stored in small amounts in specialized cells, termed secretory structures in the form of salt glands, trichomes, resin ducts, idioblasts, laticifiers, colleters and nectaries located in various reproductive and vegetative organs of the plant (Thomas, 1991). In order to understand the biological activity and composition of the secreted exudate, it is vital to know the morphology, distribution and secretory processes of the main secretory structures involved. However, these structures vary in form, distribution, function and type of secretion across different plant families. 
The family Plumbaginaceae Juss.(a.k.a the leadwort family) has about 24 genera and about 400 species (The Plant List, 2017). This is debatable because some publications reported that there are 700-800 species in the family (APG II, 2003; Simpson, 2010; Renner and Specht, 2011). Plumbaginaceae was first described in 1789 by Antoine Laurent de Jussieu and it was the only family in the order Plumbaginales. However, in 2003 the APG system of plant classification placed Plumbaginaceae in the order Caryophyllales due to certain species having carnivorous characteristics and is sister to the family Polygonaceae (Kubitzki, 1993; Perveen and Qaiser, 2004; Simpson, 2010). Plumbaginaceae comprises mainly herbs, lianas and shrubs, often occurring in saline habitats. The presence of secretory glands is characteristic of the family (Wilson, 1980; Faraday and Thomson, 1986a). Species of the Plumbaginaceae are of ornamental and medicinal importance. Plumbago auriculata Lam. an evergreen shrub is indigenous to South Africa (Figure 1) but is distibuted in other parts of the world in tropical and subtropical regions (Foden and Potter, 2015). P. auriculata occurs in thicket and shrub valley bushveld. It is often called Cape Plumbago or Cape Leadwort because it is widely found in the Cape regions of South Africa (Batten, 1986; Kubitzki, 1993; Foden and Potter, 2015). P. auriculata is an easy to manage plant as it is tolerant to high humidity, high temperature and diseases and can be treated as an ornamental as well as a medicinal plant as it contains many potent bioactive compounds (Chen and Gao, 2013). P. auriculata bears a close resemblance to Drosera, a carnivorous plant, which plays a role as an attractant as well as a repellant to many insects (Plachno et al., 2006). The genus Plumbago comprises of 18 species, three commonly studied species that is Plumbago rosea L. syn indica L., Plumbago zeylanica L., and Plumbago auriculata. In all these three species, P. auriculata is the least-studied especially in South Africa. This review focuses on information about the morphology, biology, chemical composition, pharmacology, medicinal uses and toxicity of the genus with a particular emphasis on Plumbago auriculata.

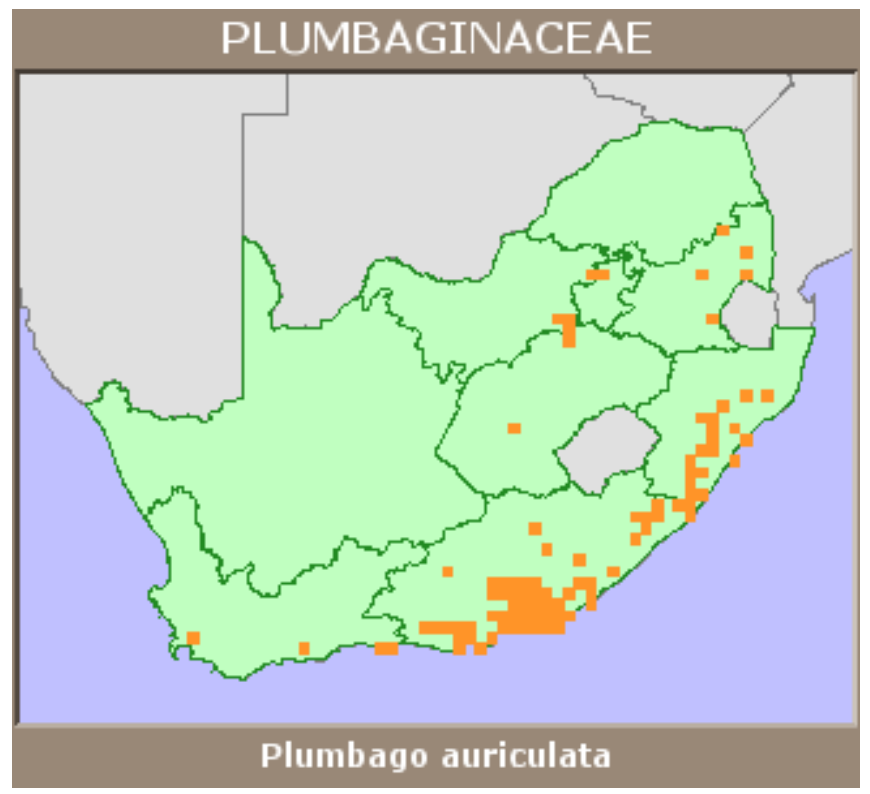

Figure 1: Distrubution of Plumbago auriculata in South Africa (After Fonden and Potter, 2015).

\section{An overview of the genus}

The genus Plumbago comprises 18 species distributed and utilised throughout the world in warm regions (APG, 2009; The Plant List, 2017). It is the largest genus in the family (APG, 2003, 2009). In Sourthen Africa 5 species are native and 2 are cultivated (Glen, 2002). Species are cultivated and utilized worldwide mostly for their medicinal and pharmacological properties due to the presence of plumbagin amongst other phytochemical compounds (Table 1) (Craven and Craven, 2000; Galal et al., 2012; Jose et al., 2014; Saha and Paul, 2012, 2014; Omwenga and Paul, 2012; Purger et al., 2012; That et al., 2012; Thamaraj and Antonysamy, 2013). The genus comprises shrubs or perennial herbs and the presence of a hairy calyx is characteristic of the genus (Batten, 1986) The hairy calyx is associated with insect entrapment amongst other functions. The most commonly cultivated and utilized species is Plumbago zeylanica with several publications (Abera et al., 2008; Chauhan, 2014; Demma et al., 2009; Jeyachandran et al., 2009; Tyagi and Menghani, 2014). 
Table 1: Species List of the genus Plumbago (The Plant List, 2017).

\begin{tabular}{|c|c|c|c|c|c|}
\hline Species Name & $\begin{array}{l}\text { Common } \\
\text { Name }\end{array}$ & Locality & Description & Traditional uses & $\begin{array}{l}\text { Pharmacological } \\
\text { uses }\end{array}$ \\
\hline $\begin{array}{l}\text { Plumbago } \\
\text { amplexicaulis } \\
\text { Oliv. }\end{array}$ & & Tanzania & $\begin{array}{l}\text { Erect herb or } \\
\text { subshrub, with } \\
\text { glaborous stems } \\
\text { and bright deep } \\
\text { blue flowers. }\end{array}$ & & \\
\hline $\begin{array}{c}\text { Plumbago aphylla } \\
\text { Bojer ex Boiss. }\end{array}$ & & $\begin{array}{l}\text { Madagascar, } \\
\text { Aldabra } \\
\text { Islands and } \\
\text { Tanzania }\end{array}$ & $\begin{array}{l}\text { Slender shrub } \\
\text { with erect stems, } \\
\text { leaves simple, } \\
\text { entire, and } \\
\text { alternate. Flowers } \\
\text { white with hairy } \\
\text { calyx. }\end{array}$ & $\begin{array}{l}\text { Used to treat } \\
\text { diarrhoea, mouth } \\
\text { infections and is } \\
\text { applied as an } \\
\text { eyewash for } \\
\text { cataract. }\end{array}$ & $\begin{array}{l}\text { Anti-bacterial and } \\
\text { antifungal. }\end{array}$ \\
\hline $\begin{array}{l}\text { Plumbago } \\
\text { auriculata Lam }\end{array}$ & $\begin{array}{l}\text { Cape } \\
\text { leadwort }\end{array}$ & $\begin{array}{l}\text { South } \\
\text { Africa, } \\
\text { Africa, } \\
\text { America, } \\
\text { Asia, India }\end{array}$ & $\begin{array}{l}\text { Bushy perennial } \\
\text { evergreen shrub, } \\
\text { trusses of pale } \\
\text { blue and white } \\
\text { flowers, leaves } \\
\text { have minute dots } \\
\text { and persistent } \\
\text { hairy calyx. }\end{array}$ & $\begin{array}{l}\text { Has many } \\
\text { therapeutic } \\
\text { properties and can } \\
\text { be used for warts, } \\
\text { fractures, oedema, } \\
\text { headaches, skin } \\
\text { lesions, piles, } \\
\text { rheumatism, } \\
\text { diarrhoea and } \\
\text { malaria and as } \\
\text { emetics. }\end{array}$ & $\begin{array}{l}\text { Antimicrobial, } \\
\text { antiulcer, } \\
\text { antimalarial, } \\
\text { antifungal, } \\
\text { anticancer. }\end{array}$ \\
\hline $\begin{array}{l}\text { Plumbago ciliata } \\
\text { Engl. }\end{array}$ & & Tanzania & & & \\
\hline $\begin{array}{l}\text { Plumbago } \\
\text { caerulea Kunth }\end{array}$ & chileno & Chile & $\begin{array}{l}\text { Shrub, with erect } \\
\text { stem and blue } \\
\text { flowers. }\end{array}$ & Ornamental value. & $\begin{array}{l}\text { Roots yield } \\
\text { plumbagin. }\end{array}$ \\
\hline $\begin{array}{l}\text { Plumbago dawei } \\
\text { Rolfe }\end{array}$ & & $\begin{array}{l}\text { Ethiopia, } \\
\text { Kenya, } \\
\text { Uganda }\end{array}$ & $\begin{array}{l}\text { Perennial herb } \\
\text { with erect stems } \\
\text { and white flowers. }\end{array}$ & $\begin{array}{l}\text { Used to treat } \\
\text { diarrhoea, stomach } \\
\text { ache.. }\end{array}$ & $\begin{array}{l}\text { Antimicrobial, } \\
\text { antimalarial }\end{array}$ \\
\hline $\begin{array}{l}\text { Plumbago } \\
\text { europaea } \mathrm{L} .\end{array}$ & $\begin{array}{l}\text { Common } \\
\text { leadwort/ } \\
\text { European } \\
\text { leadwort }\end{array}$ & $\begin{array}{l}\text { Europe, } \\
\text { Turkey }\end{array}$ & $\begin{array}{l}\text { Herbaceous half } \\
\text { shrubby, } \\
\text { multi=branched } \\
\text { plant with trusses } \\
\text { of pink or purple } \\
\text { flowers. }\end{array}$ & $\begin{array}{l}\text { Used for treatment } \\
\text { of blisters, } \\
\text { inflammation, } \\
\text { itching, toothache, } \\
\text { skin disorders. }\end{array}$ & $\begin{array}{l}\text { Antimicrobial, } \\
\text { anticancer, } \\
\text { antifungal, } \\
\text { antimutagenic and } \\
\text { insecticidal. }\end{array}$ \\
\hline $\begin{array}{l}\text { Plumbago } \\
\text { glandulicaulis } \\
\text { Wilmot-Dear }\end{array}$ & & $\begin{array}{l}\text { Kenya, } \\
\text { Tanzania }\end{array}$ & $\begin{array}{l}\text { Herb, erect hairy } \\
\text { and sticky stem } \\
\text { with leaves } \\
\text { glaborous and } \\
\text { white flowers. } \\
\end{array}$ & Ornamental value. & \\
\hline $\begin{array}{l}\text { Plumbago indica } \\
\text { L. syn. Rosea L. }\end{array}$ & $\begin{array}{l}\text { Scarlet } \\
\text { leadwort }\end{array}$ & $\begin{array}{l}\text { Asia Africa, } \\
\text { India, } \\
\text { Indonesia } \\
\text { „Phillippines }\end{array}$ & $\begin{array}{l}\text { Perennial } \\
\text { herbaceous plants } \\
\text { with erect half } \\
\text { woody stems and } \\
\text { red flowers. }\end{array}$ & $\begin{array}{l}\text { Used to treat } \\
\text { gastric acidity, skin } \\
\text { disease, } \\
\text { constipation, } \\
\text { haemorrhoids, } \\
\text { rheumatoid } \\
\text { arthritis, paralysis, } \\
\text { also used in horses } \\
\text { to expel worms, } \\
\text { also abortifacient. }\end{array}$ & $\begin{array}{l}\text { Anticancer, anti- } \\
\text { inflammatory, } \\
\text { antiatherogenic. }\end{array}$ \\
\hline $\begin{array}{l}\text { Plumbago } \\
\text { madagascariensis } \\
\text { M. Peltier }\end{array}$ & & Madagascar & $\begin{array}{l}\text { Shrub, erect stem } \\
\text { and variations of } \\
\text { blue, white and }\end{array}$ & & \\
\hline
\end{tabular}




\begin{tabular}{|c|c|c|c|c|c|}
\hline & & & purple flowers. & & \\
\hline $\begin{array}{l}\text { Plumbago montis- } \\
\text { elgonis Bullock }\end{array}$ & & $\begin{array}{l}\text { Ethiopia, } \\
\text { Kenya, } \\
\text { Tanzania }\end{array}$ & $\begin{array}{l}\text { Stout short } \\
\text { perennial herb } \\
\text { with pink flowers. }\end{array}$ & & \\
\hline $\begin{array}{l}\text { Plumbago } \\
\text { pearsonii (L.) } \\
\text { Bolus }\end{array}$ & & Namibia & $\begin{array}{l}\text { Erect shrub, } \\
\text { slightly branched } \\
\text { with pink and } \\
\text { purple- violet } \\
\text { flowers. }\end{array}$ & & $\begin{array}{l}\text { Roots yield } \\
\text { plumbagin. }\end{array}$ \\
\hline $\begin{array}{l}\text { Plumbago } \\
\text { pulchella Boiss. }\end{array}$ & $\begin{array}{l}\text { Cola de } \\
\text { iguana }\end{array}$ & Mexico & White flowers. & $\begin{array}{l}\text { vesicant and } \\
\text { caustic effect, used } \\
\text { for body aches and } \\
\text { pains, skin } \\
\text { disorders, used as } \\
\text { veterinary } \\
\text { medicine.. }\end{array}$ & Anticancer, antiulcer \\
\hline $\begin{array}{l}\text { Plumbago } \\
\text { stenophylla } \\
\text { Wilmot-Dear }\end{array}$ & & $\begin{array}{l}\text { Kenya, } \\
\text { Tanzania }\end{array}$ & $\begin{array}{l}\text { Small erect shrub } \\
\text { or woody herb, } \\
\text { white flowers. }\end{array}$ & $\begin{array}{l}\text { Skin disorders and } \\
\text { orally for } \\
\text { hookworms. }\end{array}$ & Antimalarial \\
\hline $\begin{array}{l}\text { Plumbago } \\
\text { scandens } \mathrm{L} .\end{array}$ & $\begin{array}{l}\text { Louco; } \\
\text { caataia; } \\
\text { caapomong } \\
\text { a }\end{array}$ & Brazil & $\begin{array}{l}\text { Subshrub with } \\
\text { white flowers. }\end{array}$ & $\begin{array}{l}\text { Leaves used as } \\
\text { nape compresses in } \\
\text { mentally ill } \\
\text { patients also used } \\
\text { as local anastetic. } \\
\text { Soothes toothaches } \\
\text { and earaches. } \\
\text { Reduces joint in } \\
\text { flammation. } \\
\text {-. }\end{array}$ & $\begin{array}{l}\text { Antimicrobial, anti- } \\
\text { cancer and } \\
\text { antimalarial } \\
\text { treatments. }\end{array}$ \\
\hline $\begin{array}{l}\text { Plumbago tristis } \\
\text { Aiton }\end{array}$ & $\begin{array}{l}\text { South } \\
\text { Africa }\end{array}$ & $\begin{array}{l}\text { Dark- } \\
\text { flowered } \\
\text { leadwort }\end{array}$ & $\begin{array}{l}\text { Perennial shrub, } \\
\text { dark-pink fowers } \\
\text { at the end of pink } \\
\text { hairy stems. }\end{array}$ & & $\begin{array}{l}\text { Roots yield } \\
\text { plumbagin. }\end{array}$ \\
\hline $\begin{array}{l}\text { Plumbago wissii } \\
\text { Friedr. }\end{array}$ & $\begin{array}{l}\text { Brandberg } \\
\text { Plumbago }\end{array}$ & Namibia & $\begin{array}{l}\text { Multi-stemmed } \\
\text { shrub, with violet } \\
\text { to maroon purple } \\
\text { flowers. }\end{array}$ & $\begin{array}{l}\text { Ornamental value, } \\
\text { used as a cure for } \\
\text { lead disease or lead } \\
\text { poisoning. }\end{array}$ & \\
\hline $\begin{array}{l}\text { Plumbago } \\
\text { zeylanica } \mathrm{L} .\end{array}$ & $\begin{array}{l}\text { Ceylon } \\
\text { leadwort, } \\
\text { White } \\
\text { leadwort }\end{array}$ & $\begin{array}{l}\text { Africa, Asia, } \\
\text { Australia,Et } \\
\text { hopia, India, } \\
\text { China }\end{array}$ & $\begin{array}{l}\text { Herbaceous } \\
\text { shruby plants with } \\
\text { climbing or erect } \\
\text { stems, petiolate } \\
\text { leaves and white } \\
\text { flowers. }\end{array}$ & $\begin{array}{l}\text { Used to treat } \\
\text { anemia, bronchitis, } \\
\text { rheumatism, skin } \\
\text { disorders, internal } \\
\text { and external } \\
\text { trauma, toxic } \\
\text { swelling, ulcers. }\end{array}$ & $\begin{array}{l}\text { Antibacterial, } \\
\text { antimalarial, } \\
\text { antiplasmodial, anti- } \\
\text { inflammatory, } \\
\text { antiatherosclerotic, } \\
\text { antidiabetic, } \\
\text { hypolipidaemic, } \\
\text { antifungal. }\end{array}$ \\
\hline
\end{tabular}

Blank spaces $=$ no available information.

\section{Classification of Plumbago auriculata (Fonden and Potter, 2015).}

Kingdom: Plantae

Division: Magnoliophyta

Class: Magnoliopsida

Order: Caryophyllales

Genus: Plumbago

Species: Plumbago auriculata Lam.

Common names: Cape Plumbago, Cape Leadwort, Blue Plumbago. 


\section{Morphology}

Plumbago auriculata is a perennial, bushy evergreen shrub (Figure 2a), up to $3 \mathrm{~m}$ high with erect, climbing or trailing stems that are glabrous below becoming pubescent above (Batten, 1986). The leaves are simple, elliptic to obovate, slightly discolorous, greyish green beneath and often with whitish scales seemingly for light reflection (Aubrey, 2001). Leaves are thin in texture (Figure 2b), having miniscule glandular dots, with a winged petiole at the base and auriculate. The glands found on the both surface of the leaves are reported to be salt glands (Wilson, 1890; Sakai, 1974). $P$. auriculata is covered with trusses of pale, sky blue flowers, however, there are variations of deep blue or white flowers (Figure 2b) (Batten, 1986; Ferrero et al., 2009). Flowers are salver-shaped (Figure 2d), actinomorphic and grouped in terminal inflorescences 2.5-3 cm long and flowering all year round (Luteyn, 1990; Aubrey, 2001; Ferrero et al., 2009). Corolla is pale blue with the tube twice or more than twice the length of the calyx. Glandular and non-glandular hairs, often known as trichomes, are found on the calyx (Figure 2c). Stamens are free from the corolla, included or exserted and style exserted with 5 linear stigmas and superior 1-celled ovary. Fruit is a capsule, long-beaked, the valves coherent at the apex. The seed one, dark brown or black, oblong 7mm long and slightly flattened (Luteyn, 1990; Aubrey, 2001).

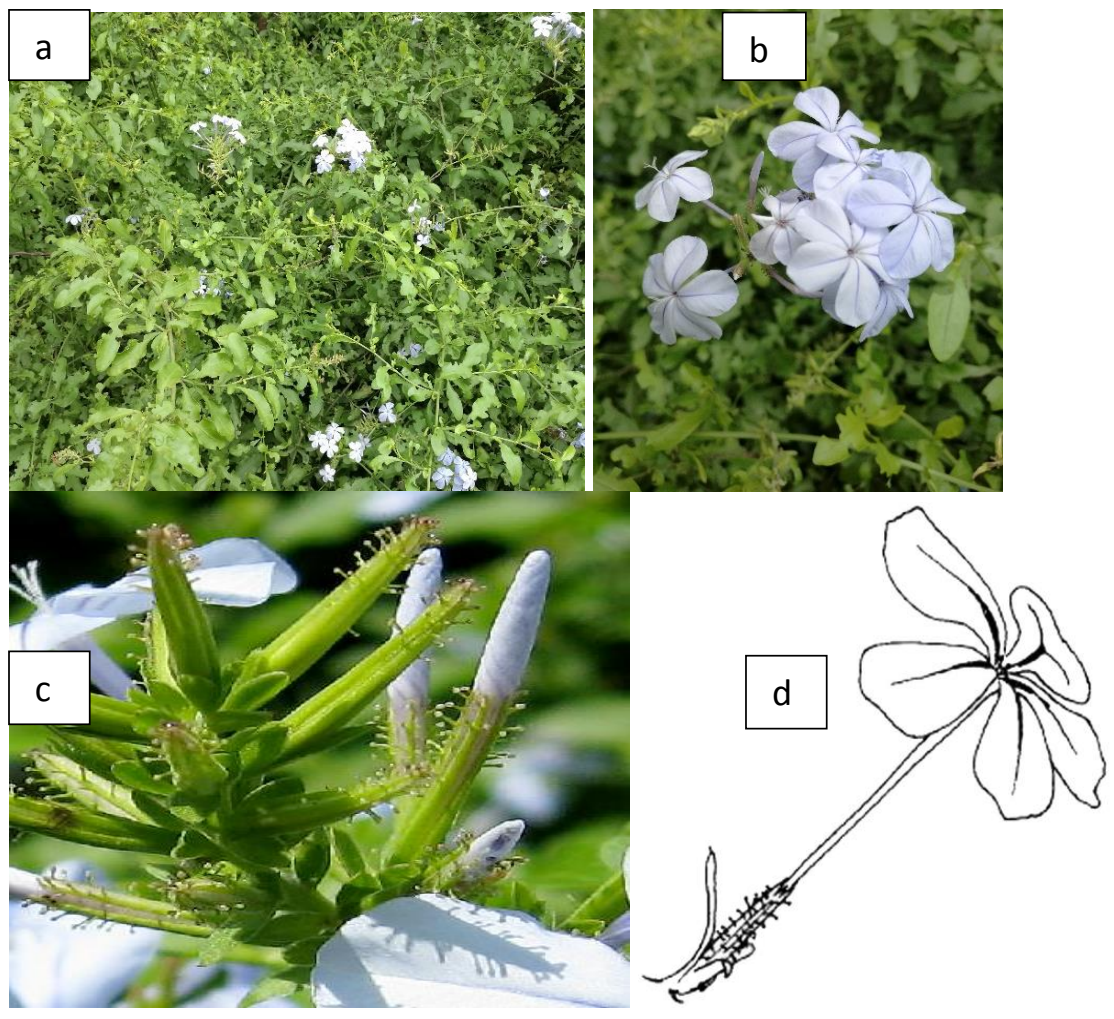

Figure 2: Plumbago auriculata: a) Bushy evergreen shrub image captured at the University of Kwazulu-Natal, Westville, Durban, South Africa; b) Variation of pale-blue flower and leaves (UKZN); c) Calyx showing trichomes; d) Illustration of flower showing calyx with trichomes (After Batten, 1986; ICPS, 1986).

\section{Secretory Structures}

Secretory structures are specialized plant structures associated with the release of substances produced in the cytoplasm and moved outside the cell (Cutter, 1978). Secretory structures appear in the form of trichomes, resin ducts, salt glands, idioblasts, laticifiers, colleters and nectaries located in various parts of the plant (Thomas, 1991). It has been reported that the primary function of secretory structures is related to defense responses against both herbivores and pathogens. (Fahn, 1988; Lange, 2015). These structures have the ability to produce or sequester secondary (or specialized) metabolites. Literature reports that salt glands occur sunken in the epidermis of leaves and are associated with ion secretion whereas trichoms protrude from the surface of leaves or stems and are often responsible for the secretion of exudates (Cutter, 1978, Fahn, 1988; Naidoo and Naidoo, 1998). Although some researchers report salt glands to be specialized trichomes, based on available literature for the purpose of this review salt glands and trichomes are classified independently as secretory structures in Plumbaginaceae (Metcalfe and Chalk, 1972; Faraday and Thomson, 1986b, Grigore and Toma, 2016). 


\section{Salt glands}

A major constraint to plant growth is salinity, which causes plants to adapt to saline environments via specialized epidermal structures known as salt glands (Kobayashi, 2008). Salt glands are highly specialized organs consisting of several cells intended to excrete salt or shift ions from mesophyll tissue to the leaf surfaces where a layer of salt crystals is formed (Figure 3b). This serves an important role in regulating salt concentration in plant tissue (Fahn, 1988; Kobayashi, 2008; Hasanuzzaman et al., 2014). Salt glands are known to secrete a wide variety of ions, especially metal ions which contribute to metal tolerance in plants once these metal ions are eliminated (Fahn, 1988, Salama et al., 1999). The most commonly secreted ions via salt glands in flowering plants are sodium, potassium, calcium and magnesium (Kobayashi, 2008). These glands also secrete other salts in addition to sodium chloride that has a composition related to that of the root environment (Storey and Thomson, 1994). Salt glands occur in halophytic species, which include several families that are not taxonomically related, thus, providing a clear example of convergent evolution on a common adaptive device (Fahn, 1988; Naidoo and Naidoo, 1998). Salt glands occur on any aerial organ of the plant but are most abundant on leaves and are inserted in the epidermis (Fahn, 1988).

Salt glands function to eliminate salts to the outside of the plant or within the plant into vacuoles (Thomson, 1975). Structurally there are three types of salt glands described (Thomson, 1975); the bicellular glands of the grasses, the bladder cells of the Oxalidaceae, Chenopodiaceae and Mesembryanthemaceae and the multicellular gland found only in dicotyledons. Regardless of the fact that the structure of salt glands varies greatly among different species, it is, very similar in plants within the same family or genus (Salama et al., 1999). Salt glands of the family Plumbaginaceae are multicellular and sunken in the leaf epidermal cells, consisting of basal and secretory cells with the cells varying in number from six up to forty (Thomson, 1975, Faraday and Thomson, 1986b). Glands were first described in the 1800's and were referred to as chalk glands due to the presence of insoluble carbonate salts found above the gland on the surfaces of stems and leaves (Grigore and Toma, 2016) . However, when it was later discovered that the glands of some species secrete sodium chloride (NACl) these glands were then referred to as salt glands ( Faraday and Thomson, 1986a; Grigore and Toma, 2016). The salt glands (Mettenius glands or Licopoli glands), as described by Grigore and Toma (2016), based on historical facts by Metcalfe and Chalk (1972), occur inside the cavities on the inner side of stems and leaves, sometimes surrounded by simple hairs or groups of elongated cells. The glands are made up of 4 to 8 epidermal cells arranged in palisade surrounded by accessory cells made up of one or two layers (Figure 3a). Cutinized walls exist between the secreting cells and the accessory cells. The salt-secreting glands of the species within Plumbaginaceae are similar in ultrastructure and morphology and the primary pathways and basic mechanisms of salt movement through the glands is the same in all species of the family (Figure 3c) (Faraday and Thomson, 1986a). These glands are able to secrete a wide variety of ions and the secretions are similar in species of the family (Storey and Thomson, 1994). Salt glands are common in the family Plumbaginaceae and sometimes these glands secrete mucilage in addition to calcium carbonate (Fahn, 1988; Grigore and Toma, 2016). Salt glands of $P$. auriculata are found on the epidermal axials of the leaves and are exo-recreto (excrete salt that form crystals on leaf surfaces) (Ceccoli et al., 2015).

a

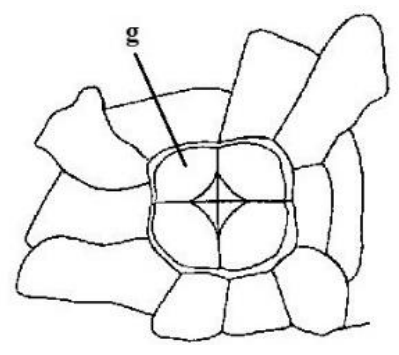

b

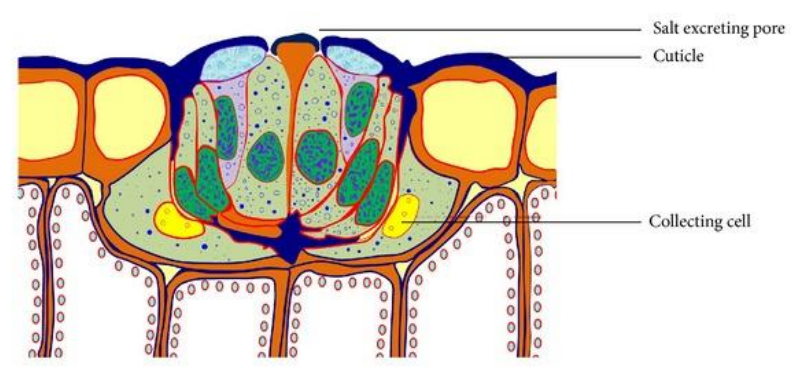




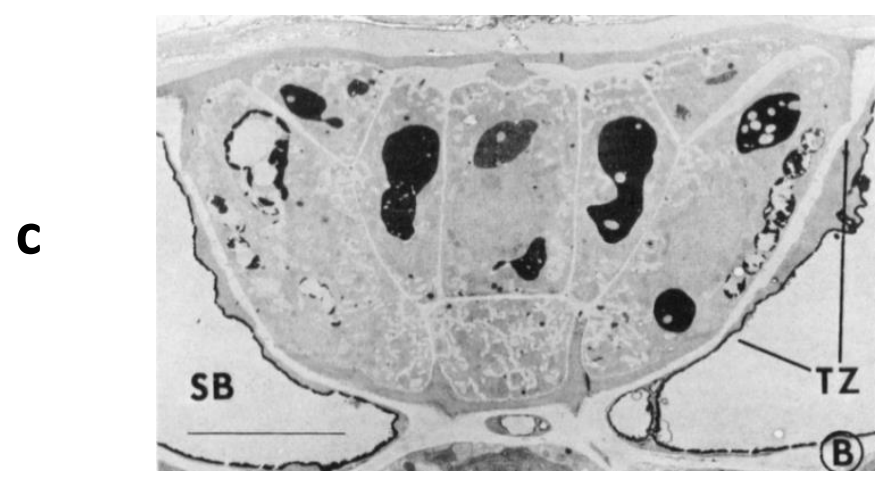

Figure 3: Structure of salt glands in various species: a) Salt glands (g) in the leaf of Plumbago europaea (After Grigore and Toma, 2016); b) ) Cross section of a generalized salt gland (After Hasanuzzaman et al., 2014); c) Electron micrograph showing the ultrastructure of an almost median longitudinal section from a secreting Plumbago auriculata salt gland (After Faraday and Thomson, 1986a); TZ-Transfusion zone; SB- subbasal cell; Scale bar $80 \mu \mathrm{m}$.

\section{Trichomes}

Trichomes are often referred to as epidermal appendages that can either be singular or multicellular, developing outwards on the surface of plant organs (Payne, 1978; Fahn, 1988). Their morphology varies greatly among tissue and species and according to botanical literature there are over 300 descriptions to characterize various morphological types, outlining a few in (Figure 4) (Payne, 1978; Wagner, 1991). Trichomes occur in all major groups of terrestrial plants and are needed to carry out the following functions: light reflectance; reduction of waterloss through transpiration; thermoregulation; herbivory; defence against radiation, pathogen attack. However, the role of trichomes can be considered species specific (Wagner, 1991; Bauer et al., 2015). As outlined by Payne (1978), trichomes can be either glandular or nonglandular and are often found occurring on different parts of the plant. Glandular trichomes are the primary secretory structures in most flowering plants and distributed over the vegetative aerial part of plants (Kaya et al., 2006). They vary in their structure, function and location as well as chemical compostion in the substances they secrete (Payne, 1978; Rusydi et al., 2013). Morphologically, glandular trichomes are classified as either peltate or capitate and generally consist of a foot, a stalk that is usually unicellular or bicellular and a secretory head (Payne, 1978; Ascensao et al., 1997; Salmaki et al., 2009). Capitate trichomes vary widely in stalk length, head shape and secretion type but a general rule is that the stalk length measures more than half the height of the head whereas peltate trichomes are usually made up of a short wide stalk, several head cells and one basal epidermal cell ( Ascensao and Pais, 1998; Kaya et al., 2006). Capitate trichomes secrete a small amount of essential oils and some polysaccharides and these exudates are mostly excreted to the surrounding environment via pores in the cuticle of the head cell (Kamatou et al., 2007). The peltate trichomes are most important for essential oil production because most of the secretory cells are in the head and the exudates are stored in the subcuticular spaces between the head cell walls and the cuticle. They function as storage structures for the secreted exudates (Salmaki et al., 2009).

Non-glandular trichomes are also found occurring on the aerial vegetative parts of the plant as well as within plant tissue and can be described as follows (Fahn, 1988; Maclachlan and Carlquist, 1992): a) simple unicellular or multicellular, non flattened hairs; b) squamiform hairs which are conspicuously flattened, multicellular hairs. These trichomes are termed 'scales' if they are sessile or peltate hairs if they are stalked; c) branched, multicellular hairs which may be stellate; d) shaggy hairs which consist of a base and two or more contiguous rows of cells. The function and location of non-glandular trichomes are species-specific. Non- glandular trichomes of some Kalanchoe spp demonstrated how diverse these type of trichomes are in terms of length, number of cells in the stalk, shape of the upper part, density of occurrence , occurence of wax on their surface and cuticle ornamentation (Weryszko-Chmielewska and Chernetskyy, 2005). Trichome viability also acts as a determinant for the function of the trichome i.e. dead non-glandular trchomes found on the surface of Kalanchoe leaves provide a protective structure to the leaves enabling surface moisture. The function of trichomes is dependent on the species as well as the environment. 


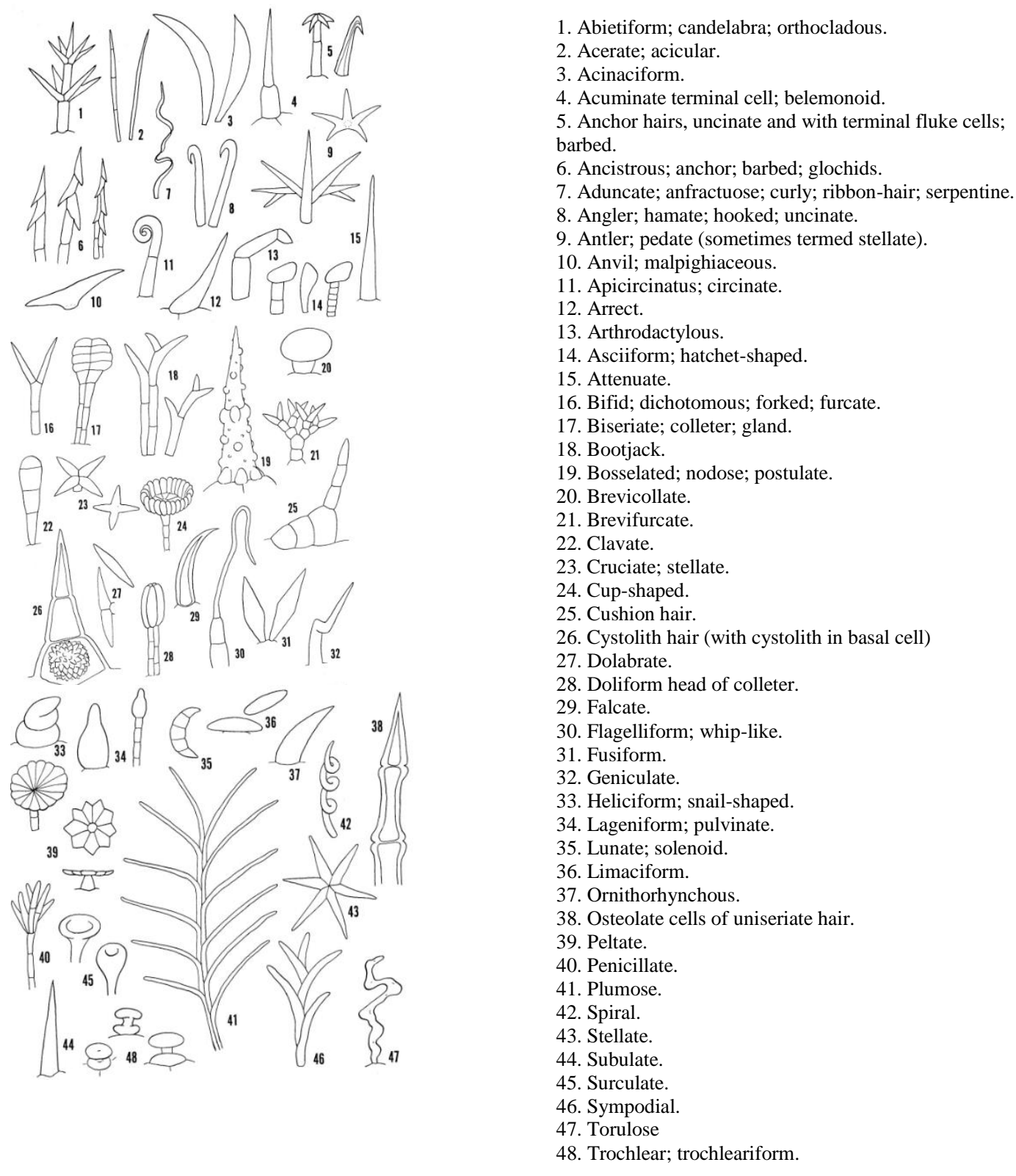

Figure 4: Trichome types (After Payne, 1978)

The calyx of $P$. auriculata bear large mucilage secreting trichomes (Figure 5a), which resemble those of the genus Drosera (Droseraceae) and Drosophyllum (Droserophyllaceae) that also occur in the order Caryophyllales (Stoltzfus et al., 2002; Panicker and Haridasan, 2016). The trichomes on the calyx can also be termed "colleters" meaning it secretes a sticky substance and usually consist of a multicellular stalk and head. However due to its close resemblance to Drosera the trichomes can also be considered as digestive glands due to their function in insect entrapment (Figure 5b) (Fahn, 1952). Naidoo and Heneidak (2013), studied the glandular hairs of Drosera capensis L. and reported that the leaves are characterized by eight types of glandular hairs with a red-coloured stalk and stalk head making it more attractive to insects These trichomes function to capture and entrap insects, absorb nutrients, produce mucilage and digestive enzymes, as well as secrete proteases in response to stimulation by certain salts (Stoltzfus et al., 2002; Naidoo and Heneidak, 2013; Bauer et al., 2015). Trichomes of Droseraceae were also found to exhibit phosphatase activity in the external glands (Plachno et al., 2006). Studies by Rashmilevitz and Joel (1976), mentioned in Stoltzfus et al. (2002), that trichomes of Plumbago have a resinous secretion and showed a positive response when stained with Sudan IV, therefore proving it has a substantial hydrophobic constituent. It was reported that trichomes of the genus Plumbago exclude crawling insects from the flowers, therefore favouring flying insects for cross pollination (Jose et al., 2014) Trichomes of $P$. auriculata produce a sticky transparent exudate which traps winged insects which resembles a cobweb. The exudate is known to turn brown upon maturity of the plant in Plumbago species, however nothing has been reported with regards to P. auriculata. (Panicker and Haridasan, 2016). Non-glandular trichomes are also found on the calyx of $P$. auriculata (Figure 5c), but the function of the 
trichomes is unknown in this species. However, it has been reported in other species that these trichome types provide shade to the plant and serve as a mechanical barrier to prevent insects from piercing the leaf (Gonzales et al., 2008).

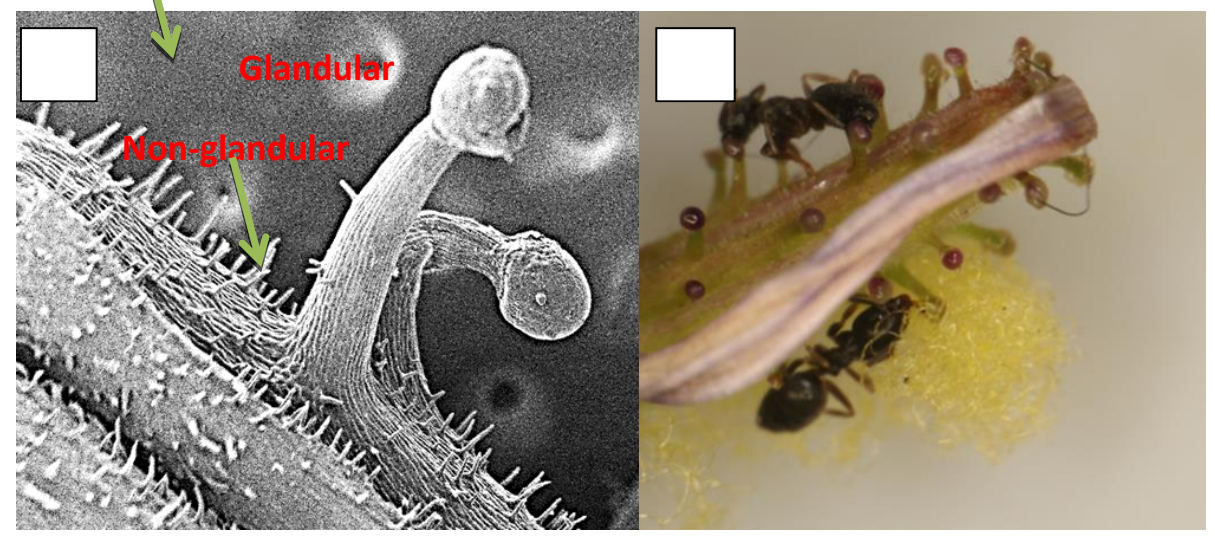

Figure 5: Types of trichomes on the calyx of Plumbago auriculata: a) Scanning electron microscopy (SEM) micrograph of glandular trichomes and non-glandular trichomes; b) SEM micrograph of an ant captured on calyx. Scale bar $100 \mu \mathrm{m}$.

\section{Chemical Composition}

Plants are of great importance to humans for use as ornaments, food preparations and medicines.. The use of herbal medicines has always been in great demand (Balunas and Kinghorn, 2005). There is an intense interest in medicinal plants in which phytochemical constituents can have long-term health promoting properties (Kennedy and Wigthman, 2011). Plants naturally produce secondary metabolites, commonly referred to as phytochemicals or biologically active compounds that exhibit a holistic healing approach (Kennedy and Wigthman, 2011). These include alkaloids, saponins, tannins, glycosides, flavonoids, terpenoids, naphthaquinones, carbohydrates, proteins, phenolic compounds, fixed oils and fats (Katsoulis et al., 2000; Pourmorad et al., 2006). Alkaloids and phenolic compounds are often the two major phytochemical compounds that are of medicinal importance. A wide range of medicinal properties of $P$. auriculata are attributed to plumbagin and other secondary metabolites.

\section{Phytochemical Screening}

Methanolic leaf extract of $P$. auriculata revealed the presence of the following phytochemicals- tannins, flavonoids, phenols, alkaloids, saponins, proteins, and carbohydrates with phenols being the most abundant compound (Lakshmanan et al., 2016). Aerial parts of $P$. auriculata extracted in the following solvents: acetone, chloroform, petroleum ether, ethanol and ethyl acetate showed positive results when tested for steroids, carbohydrates, phenolics, tannins, saponins, flavonoids and terpenoids, however the aqueous extract only showed positive for the presence of tannins (Tharmaraj and Antonysamy, 2013). It can be concluded that aqueous extractions are not as effective as other solvents for phytochemical screening. Systematic fractionation and phtochemical examination of the methanolic root extract of

\section{Bioactive Compounds}

$P$. auriculata revealed the presence of the following compounds: $\alpha$-amyrin, capensisone, $\alpha$-amyrin acetate, isoshinanolene, $\beta$-sitosterol, diomuscinone, plumbagin and $\beta$-sitosterol-3 $\beta$-glucoside (Table 2)(Padhye et al., 2010; Ariyanathan et al., 2011; Saeidnia et al., 2014; Khan and Hossain, 2015). Capensisone is a novel quinone that was first to be characterized from the roots of $P$. capensis and, in their study, isoshinanolone and diomuscinone were reported for the first time for the genus Plumbago (Ariyanathan et al., 2011).

Table 2: Bioactive compounds reported in plant extracts of Plumbago auriculata

\begin{tabular}{|l|l|}
\hline Compounds & Medicinal/ pharmacological uses \\
\hline Plumbagin & $\begin{array}{l}\text { Anticancer, antifungal, anti-inflammatory, antibacterial, } \\
\text { antifertility, antimalarial, antidiabetic and antioxidant } \\
\text { properties. }\end{array}$ \\
\hline$\alpha$-amyrin and $\alpha$-amyrin acetate & \\
\hline capensisone & Antibacterial and antifungal properties. \\
\hline isoshinanolene & Heart disease and high cholesterol, gallstones, common \\
\hline$\beta$-sitosterol (Beta-sitosterol)
\end{tabular}




\begin{tabular}{|l|l|}
\hline & $\begin{array}{l}\text { cold and flu, rheumatoid arthritis, asthma, migraine } \\
\text { headaches, menopause symptoms, enlarged prostrate, } \\
\text { chronic fatigue syndrome, cervical cancer. It also boosts } \\
\text { the immune system and prevents colon cancer as well as } \\
\text { enhances sexual activity. }\end{array}$ \\
\hline$\beta$-sitosterol-glucoside & $\begin{array}{l}\text { Antioxidant, hypertension and antidiabetic properties } \\
\text { (used to control menstrual bleeding. }\end{array}$ \\
\hline diomuscinone & $\begin{array}{l}\text { Wound healing, antimicrobial and anti-inflammatory } \\
\text { properties. }\end{array}$ \\
\hline
\end{tabular}

\section{Plumbagin}

In the genus Plumbago, a highly potent and broad spectrum biological compound known as plumbagin is commonly found (Tyagi and Menghani, 2014). Plumbagin is a 5-hydroxy-2-methyl-1,4-naphthoquinone- $\left(\mathrm{C}_{11} \mathrm{H}_{8} \mathrm{O}_{3}\right)($ Figure 7) present in the roots, stems and leaves of various Plumbago species; with the roots predominantly having the highest concentration of plumbagin (Padhye et al., 2010). Plumbagin is naturally a yellow pigment that was first isolated in 1829 via solvent extraction of powdered plant material and has since been of interest for research due to its high medicinal value (Tyagi and Menghani, 2014). Plumbagin is soluble in a variety of solvents such as acetone, benzene, alcohol, methanol, acetic acid and chloroform. Plumbagin exhibits anticancer, antifungal, anti-inflammatory, antibacterial, antifertility, antimalarial, antidiabetic and antioxidant properties (Mallavadhani et al., 2002; Checker et al., 2009; Padhye et al., 2010; Jose et al., 2014). It is also reported to have other therapeutic properties such as stimulant action on the intestine, nervous system and heart as well as rheumatic pain relief (Galal et al., 2012). All parts of $P$. auriculata contain plumbagin with the highest amount of plumbagin accumulating in the leaves and stems of the plant in comparison to $P$. zeylanica and $P$. rosea (Jose et al., 2014). This shows that different species accumulate plumbagin in different parts of the plant.

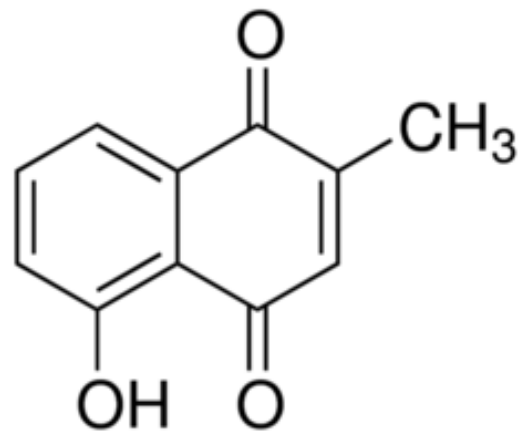

Figure 6: Structure of Plumbagin (After Padhye et al., 2010).

\section{Mode of Action of Plumbagin Anticancer activities}

Plumbagin displays anticancer activities over a wide range of tumors such as breast cancer, ovarian cancer, prostrate cancer, pancreatic cancer, lung cancer, skin cancer, leukemia, liver cancer, renal cancer, cervical cancer. Studies have revealed that plumbagin is an effective inhihibitor of cell growth and when administered in combination with radiotherapy plumbagin has the ability to augment cell growth inhibition very effectively in comparison to a higher dose of radiation alone. (Padhye et al., 2010). Extensive publications exist on the anticancer effect of plumabin outlined in Padhye et al (2010).

\section{Antifungal activities}

The findings of the antifungal activity of plumbin by Dzoyem et al. (2007) suggested that the naphthoquinone delayed germination of the fungus and was capable of inhibiting growth when abministered at higher concentrations.

\section{Anti-inflammatory}

Plumbagin has been reported to be a topoisomerase-II inhibitor by displaying inhibitory activities of corresponding enzymes involved in rheumatoid arthritis (RA) (Jackson et al., 2008). Checker et al (2009) reported that plumbagin suppresses NF-kB (ubiquitous transcription factor) activation in tumor cells, and hence might have an effect on biological functions of leukocytes actively participating in various immune responses. 


\section{Antibacterial activity}

Extensive publications reported the antibacterial activity of plumbagin as outlined by Padye et al (2010). However to summarize these findings, plumbagin displays potent antibacterial activity against a range of bacterial strains such as: Staphylococcus aureus, Myobacterium smegmatis and various Myobacterium tuberculosis strains and Escherichia coli. However, plumbagin does display cytotoxic activity and needs to be administered at the appropriate concentration.

\section{Antifertility activity}

Plumbagin has been reported to be an irritant to the smooth muscle of the uterus when administered orally at high concentrations. Therefore it needs to be administered with caution. Madhavan et al (2009) reported that antifertility effects were found to be effective with doses of $1 \mathrm{mg} / 100 \mathrm{gm}$ of body weight in female rats. Plumbagin also displays a significant effect on estrogen cycle and hormonal levels of female rats.

\section{Antimalarial activity}

Antimalarial activity of plumbagin was reported by Sumsakul et al (2014) by investigating In vitro antimalarial activity of plumbagin against K1 and 3D7 Plasmodium falciparum and In vivo antimalarial activity in Plasmodium bergheiinfected mouse model (a 4-day suppressive test). Their study concluded that plumbagin exhibited efficient antimalarial activity in both In vivo and In vitro experiments and displayed a fairly low toxicity at the dose levels up to 100 (single oral dose) and 25 (daily doses for 14 days) $\mathrm{mg} / \mathrm{kg}$ body weight for acute and subacute toxicity.

\section{Antidiabetic}

It was reported that orally administered plumbagin significantly reduced the blood glucose levels and altered all other biochemical parameters to near normal. Further, it increased the activity of hexokinase and decreased the activities of glucose-6-phosphatase and fructose-1,6-bisphosphatase in diabetic rats. Plumbagin also enhanced GLUT4 mRNA and protein expression. It also contributed to glucose homeostasis. (Sunil et al., 2012).

\section{Antioxidant}

Plumbagin contributes to EGFR activation in ROS-related mechanisms (Padhye ett al., 2010). It was also found to significantly reduce the catechol-induced DNA damage, and inhibit ascorbate and NADPH-dependent lipid peroxidation against mouse lymphoma cells (Demma et al., 2009).

\section{Medicinal Uses and Pharmacology of Plumbago auriculata Extracts}

Plumbago auriculata has a strong medicinal value and for many years has been used in the traditional medicinal market as an alternate remedy for the prevention and control of certain human ailments. All parts of the plant are reported to have therapeutic properties for example, the leaves and roots have cardiotoxic, neuroprotective, anti-atherogenic and hepatoprotective properties (Deshpande et al., 2014). Roots and leaves are also reported to be used for warts, as emetics, fractures, oedema, headaches, skin lesions, piles, rheumatism, diarrhoea and malaria (Elgorashi et al., 2003; Chen and Gao, 2013). In Mozambique where malaria is endemic, aerial parts of $P$. auriculata are used for the treatment of symptoms associated with malaria such as vomiting and fever (Ramalhete et al., 2008). In Manchale, a rural village in India, it was reported that herbal healers use the root of the plant for the treatment of piles by forming a paste with water and applying directly (Poornima et al., 2012). Certain indian tribes also make use of the root extract by preparing fresh roots in rainwater and drinking for a week to combat acidity (Jain et al., 2010). Plants are not only used for the treatment and control of human ailments but it has been reported that plant extracts can also be used in ethnoveterinary as low-cost treatments for diseases of livestock and other animals (McGaw and Eloff, 2008). Root extracts of P. auriculata are used in as a treatment for diarrhaea in cows (Dold and Cocks, 2001). A fair amount of studies have been conducted to isolate and evaluate the pharmacological activities of the extracts of $P$. auriculata.

\section{Antiulcer Activity}

Different species of Plumbago plants were collected from different regions of Kerala, India. Roots of plants were dried and coarsely powdered, soaked in limewater and then extracted using ethanol as a solvent (Ittiyavirah and Paul, 2016). Goat intestines were used to test for antiulcer activity of the ethanolic root extracts by treating small pieces of the intestines (1.5-2 cm long) with $1 \mathrm{ml}$ P.auriculata extract. The results of this study reported that $P$. auriculata showed 
significant acid neutralizing capacities as well as excellent antioxidant properties observed from the DPPH assay. The use of goat intestine can be used as a standard test for in vitro antiulcer activities of plant extracts.

\section{Antifungal Activity}

Fresh plant material of $P$. auriculata such as roots, leaves, stems and flowers were extracted using distilled water as a solvent (Rajasekaran et al., 2015). Each extract was then mixed with a $1 \mathrm{mM}$ silver nitrate solution in a 1:10 ratio to form a silver nanoparticle. Only the root, flower and stem extracts were effective in the synthesis of silver nanoparticles and were further used in the application of the newly synthesized nanoparticles for antifungal activity. Antifungal activity was tested by spore germination assay on the following fungi: Aspergillus fumigatus, Fusarium oxysporium, Aspergillus flavus, Curvularia lunata and Trichoderma sp. Results of this study reported that the efficacy of the particle reflects on its size i.e. bigger paritcles were effective on larger spore such as Curvularia lunata and ineffective against smaller spore bearing fungi (Rajasekaran et al., 2015)

\section{Antibacterial Activity}

Roots of $P$. auriculata were dried and ground to a fine powder and, active components were extracted using the following solvents water, chloroform, methanol and ethanol (Muringani and Makwikwi, 2017). Antibacterial activity was tested using the kerbybaur disc diffusion method. Bacterial strains used were about 150 E.coli isolated from water and patient stool samples from the Mthata Region, Eastern Cape, South Africa. The results of this study reported that the ethanolic root extract showed the highest rate of activity against all the examined strains of the E. coli samples. Antibacterial activity of aerial parts of Plumbago species have also been reported. Aerial parts of the plants were dried and extracted using various solvents and antibacterial assay was determined using the agar-well diffusion method (Tharmaraj and Antonysamy, 2015). The following bacterial strains used were Streptococcus pyrogenes, Pseudomonas aeruginosa, Staphylococcus aureus, Bacillus subtilis, Morganella morganii and Bacillus subtilis and antibiotic amikacin (30 $\mu \mathrm{g} / \mathrm{disc})$ was used as a standard to compare its effect on the bacterial strains with the plant extracts. The results of the study for P.auriculata reported that the ethanolic extract showed the highest activity (70\%) and the highest zone of inhibition $(23 \pm$ $0.3 \mathrm{~mm}$ ), followed by petroleum ether and chloroform extracts. The ethanolic extract of P. auriculata showed above $50 \%$ activity against Gram positive bacteria and $26 \%$ against Gram negative bacteria. The overall results of the study showed that $P$. zeylanica and $P$. rosea had the highest activity against Gram positive bacteria whilst $P$. auriculata had the least activity and the antibacterial potentials of Plumbago species is probably due to the presence of alkaloids and phenolic compounds (Tharmaraj and Antonysamy, 2015).

Plasmid-mediated multiple drug resistance is a serious and emerging problem in the treatment of infectious diseases because bacteria have become resistant to most of the drugs available. Scientists have developed a way to combat this problem by combining herbal extracts with antibiotics to inhibit the development and spread of R-plasmids (Patwardhan et al., 2015). P. auriculata root extracts were used to cure plastid-mediated antibiotic resistance, The plasmids curing activity of the root extract was determined by growing Escherichia coli, Proteus vulgaris and Klebsiella pneumonia, in the root extract. Ethanol root extract demonstrated the highest antibacterial activity as well as the maximum plastid curing activity (13-32\%) compared to chloroform, acetone or petroleum ether root extracts. P. auriculata root extracts can be used as plasmid curing agents in the treatment of nosocomial infections.

\section{Cytotoxic activity}

Gastric ulcer is one of the most common gastrointestinal disorders in recent times (Paul et al., 2013). AntiHelicobacter and cytotoxic activity of detoxified ethanol root extracts of $P$. auriculata were assessed by preparing the roots in lime water and extracting them using ethanol as a solvent (Paul et al., 2013). Cell viability was assessed by Microculture tetrazolium (MTT) Assay in the presence and absence of different plant extracts. The study reported that the ethanol root extract has possible activity against H.pylori, cytotoxicity with MTT assay HGE-17 cell lines and the zone of inhibition test of P. auriculata ethanol root extracts showed significant activity. Paul et al. (2013), also revealed in their study that Plumbago species show cytotoxic activity, even in the absence of bioactive plumbagin.

Methanolic leaf extracts also showed significant cytotoxic activity when assayed against human lung cancer (A549) and ovarian cancer (PAI) cell lines using MTT assay (Lakshmanan et al., 2016). For A549, it showed a minimum cytotoxic activity at $45 \mu \mathrm{g} / \mathrm{ml}$ and $10 \mu \mathrm{g} / \mathrm{ml}$ cell line and for PAI $10 \mu \mathrm{g} / \mathrm{ml}$ and $60 \mu \mathrm{g} / \mathrm{ml}$ cell line at 24 hours and 48 hours, respectively.

\section{Anticancer Activity}

Cancer is a common, most dreadful life threatening disease reported worldwide and is often difficult to control and cure (Balunas and Kinghorn, 2005). Bioactive compounds extracted from plants are being extensively researched and utilized as a possible anticancer agent. In vitro P. auriculata leaves were dried and extracted using methanol as a solvent 
(Lakshmanan et al. 2016). The leaf extract was tested against ovarian (PAI), lung (A549) and malignancy cell lines for apoptotic and anti-proliferative activities. The GC-MC analysis of the methanolic extract revealed the presence of the

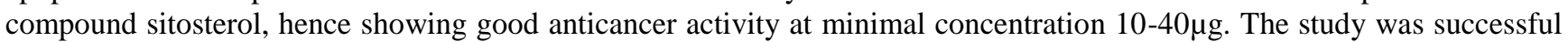
in reporting that $P$. auriculata constitutes novel anticancer compounds.

\section{Toxicity}

Bioactive compounds found in plants often have many therapeutic uses and are of high medicinal value. Hoiwever, these compounds can exhibit toxic effects which can result in detrimental side-effects . Plumbagin, often referred to as the marker compound in the genus Plumbago is also toxic, as it generates superoxide anion reactive oxygen species that can damage various biomolecules (Jose et al., 2014). It is a powerful irritant in low doses that inhibits cell mitosis and, in higher than recommended doses, it can cause death from respiratory failure, paralysis as well as nucleotoxic and cytotoxic effects. Other commonly known side effects of plumbagin include skin rashes, diarrhoea, increase in neutrophil counts and white blood cells, hepatic toxicity and increase in acid phosphatase and serum phosphatase levels (Padhye et al., 2010). P. auriculata is assigned to toxicity class 4 meaning the juice sap or thorns of the plant can have adverse effects on the skin, resulting in dermatitis (Stone and King, 1997). It has been reported that traditional tribes in India that make use of roasted $P$. auriculata roots for wound healing use very small quantitites and for a limited time period because prolonged exposure and large quanties can lead to death by irritation (Jain et al., 2010).

\section{Propagation Techniques}

Plumbago auriculata makes a good ornamental plant that can be planted indoor or outdoors. Plant management is quite simple because of tolerance to high humidity, high temperatures and diseases and even though the plant secretes salt it is not limited to saline conditions (Joy et al., 1998; Aubrey, 2001). The common propagation method of this species is seed sowing. However, seed germination rate is very low and seed prices are often too expensive (Batten, 1986; Chen and Gao, 2013). Due to its high medicinal value, the conventional method of propagating $P$. auriculata is often difficult and cannot meet the growing demand for the plant in the traditional medicine and pharmaceutical markets due to poor germination and death of young seedlings under natural conditions. Therefore, researchers have developed plant tissue-culture as a method to produce seedlings which have certain advantages over conventional propagation methods. Chen and Gao (2013.), micropropagated 1 year old plants of P.auriculata using the nodals and leaves. They concluded that young nodals are best to use as explants because leaves have a high differentiation grade and the ability of regeneration is weak. Deshpande et al. (2014), reported that P.auriculata increased callus in vitro mass production by using various growth hormones such as indoleacetic acid (IAA), 1-Naphthaleneacetic acid (NAA) and Indole-3-butyric acid (IBA). IAA is a simple compound (auxin) that assists in plant growth and development (Davies, 2004). IBA is most commonly used commercially for plant propagation due to its efficacy to stimulate adventitious root growth and is often more stable than IAA against in vivo catabolism (Davies, 2004). NAA is a synthetic plant hormone widely used in agriculture, horticulture and plant tissue culture to increase cellulose fiber formation (Davies, 2004). However, it is toxic to the plant in high concentrations. Growth hormone NAA exhibited higher production of callus formation in all the explants; combination of hormones IBA and NAA showed best callusing from leaf explants. Combinations of BAP and NAA showed best callusing from stem and shoot apex explants. BAP are synthetic cytokinins used in tissue culture to promote cell division, bud formation and stem branching (Zhang et al., 2005; Madhavam et al., 2009). It has been reported that this species can also be propagated vegetatively by placing $15 \mathrm{~cm}$ long stem cuttings in polybags and applying IAA and IBA treatments to improve rooting (Joy et al., 1998; Lakshmanan et al., 2016).

In related studies plumabin production was enhanced using root cultures of Plumbago indica L. through precursor feeding using 1-alanine followed by in situ adsorption of plumbagin on the nonpolar copolymer adsorbent, styrenedivinylbenzene resin (Diaion ${ }^{\circ}$ HP-20) (Jaisi and Panichayupakaranant, 2017) Roots were fed with L-alanine (concentration $5 \mathrm{mM}$ ) for 14 days followed by the sequential addition of Diaion ${ }^{\circledR} \mathrm{HP}-20(10 \mathrm{~g} \mathrm{~L}-1)$ after 36 hours of Lalanine-feeding. Plumbagin production was significantly increased. Productivity levels obtainted were higher than that achieved using untreated root cultures or L-alanine feeding alone. Jaisi and Panichayupakaranant (2017) concluded that their study suggests the use of precursor feeding in combination with in situ adsorption as an easy and cost effective tool for the commercial production of medicinally important bioactive compounds like plumbagin. Overall tissue culture is a beneficial propagation technique for increasing plumbagin production in Plumbago spp as well as the production of other medicinal plant compounds.

\section{Conclusion}

The genus Plumbago yields many medicinally important species throughout the world. There is a lack in knowledge on some species within the genus thus providing an opportunity for future research. This review clearly shows the importance of Plumbago auriculata as a useful medicinal plant and also its level of toxicity. This species is used throughout the world, however limited research exists in South Africa where it is native. While the morphology of 
trichomes has been studied, the detailed trapping mechanisms of insects are still unknown. The structure and function of secretory structures occurring in this species are not well documented. Although much pharmacological studies have been conducted, studies on the secretory structures are limited to only a small number of publications dealing with secretory structures, especially the types of trichomes present and ultrastructure of the leaf glands. However, the nature of the secretions from these structures are unknown. Micropropagation results viewed in this study are aimed at encouraging and attracting researchers to promote rapid regeneration of $P$. auriculata to ensure easy availability of the plant for horticulture, medicinal and pharmacological uses. The use of plant hormones in tissue culture techniques proved to be effective in optimizing the production of medicinal plants, thus increasing the availability of bioactive compounds. Other techniques such as genetic engineering has not yet been explored for the genus and could prove useful in commercializing this medicinally important genus.

Acknowledgements: The authors wish to thank the University of KwaZulu Natal, Westville Campus for providing the resources needed to conduct the research. The National Research Foundation (NRF) for funding this research.

Conflict of interest: The authors declare that there is no conflict of interest.

\section{References}

1. Abera, B., Negash, L. and, Kumlehn, J. (2008). Reproductive biology in the medicinal plant, Plumbago zeylanica L. African Journal of Biotechnology 7: 3447-3454.

2. Angiosperm Phylogeny Group (APG II). (2003). An update of the Angiosperm Phylogeny Group classification for the orders and families of flowering plants: APG II. Botanical Journal of the Linnean Society 141: 399-436.

3. Angiosperm Phylogeny Group (APG III). (2009). An update of the Angiosperm Phylogeny Group classification for the orders and families of flowering plants: APG III. Botanical Journal of the Linnean Society 161: 105-121.

4. Ariyanathan, S., Saraswathy, A. and, Rajamanickkam, G.V. (2011). Phytochemical investigation of Plumbago capensis Thunb. International Journal of Pharmacy and Life Sciences 2: 670-673.

5. Ascensao, L., Marques, N. and, Pais, M.S. (1997). Peltate glandular trichomes of Leonotis leonurus leaves: Ultrastructure and histochemical characterization of secretions. International Journal of Plant Sciences 158: 249-258.

6. Ascensao, L. and, Pais, M.S. (1998). The leaf capitate trichomes of Leonotis leonurus: histochemistry, ultrastructure and secretion. Annals of Botany 81: 263-271.

7. Aubrey, A. (2001). Plumbago auriculata Lam, In: South African National Biodiversity Institute. http://www.sanbi.org/frames/posafram.htm. Downloaded on 27 April 2015.

8. Balunas, M.J. and, Kinghorn, A.D. (2005). Drug discovery from medicinal plants. Life sciences 78: 431-441.

9. Batten, A. (1986). Flowers of Southern Africa. Frandsen Publishers. Sandton. 401pp.

10. Bauer, U., Scharmann, M., Skepper, J. and, Federie, W. (2015). Insect aquaplaning on a superhydrophilic hairy surface: how Heliamphora nutans Benth. pitcher plants capture prey. Proceedings of the Royal Society of Botany 280: 1-6.

11. Ceccoli, G., Ramos, J., Pilatti, V., Dellaferrera, I., Tivano, J.C., Taleisnik, E. and Vegetti, A.C. (2015). Salt glands in the Poaceae family and their relationship to salinity tolerance. Botanical Review 81: 16-178.

12. Chauhan, M. (2014). A review on morphology, phytochemistry and pharmacological activities of medicinal herb Plumbago zeylanica Linn. Journal of Pharmacology and Phytochemistry 3: 95-118.

13. Checker, R., Sharma, D., Sandur, S.K., Khanam, S. and Poduval, T.B. (2009). Anti-inflammatory effects of plumbagin are mediated by inhibition of NF-kappaB activation in lymphocytes. International Immunopharmacology 9: 949-958.

14. Chen, Y.L. and Gao, S. (2013). Preliminary report of PGR's influence to multiple shoot induction and plant regeneration on Plumbago auriculata. American Journal of Plant Sciences 4: 23-29.

15. Craven, P. and, Craven, D. (2000). The flora of the Brandberg, Namibia. Cimbebasia Memoir 9: 49-67.

16. Cutter, E.C., (1978). Plant Anatomy Part 1: Cells and tissues. Edward Arnold Publishers Ltd. London. 315pp.

17. Davies, P.J. (2004). Plant hormones. Biosynthesis, Signal transduction, Action! $3^{\text {rd }}$ edition, Kluwer Academic Publishers, Netherlands. 776pp.

18. Demma, J., Engidawork, E. and, Hellman B. (2009). Potential genotoxicity of plant extracts used in Ethiopian traditional medicine. Journal of Ethnopharmacology 122: 136-142.

19. Deshpande, J., Labade, D., Shankar, K., Kata, N., Chaudhari, M., Wani, M. and, Khetmalas M. (2014). In vitro callus induction and estimation of plumbagin content from Plumbago auriculata Lam.Indian Journal of Experimental Biology 52: $1122-1127$.

20. Dold, A.P. and Cocks, M.L. (2001). Traditional veterinary medicine in the Alice district of the Eastern Cape Province, South Africa. South African Journal of Science 97: 375-379.

21. Dzoyem, J.P., Tangmouo, J.G., Lontsi, D., Etoa, F.X. and, Lohoue, P.J. (2007). In vitro antifungal activity of extract and plumbagin from the stem bark of Diospyros crassiflora Hiern. (Ebenaceae). Phytotherapy Research 21: 671-674.

22. Elgorashi, E.E., Taylor, J.L.S., Maes, A., van Staden, J., De Kimpe, N. and, Verschaeve L. (2003). Screening of medicinal plants used in South African traditional medicine for genotoxic effects. Toxiology Letters 143: 195-207.

23. Fahn, A. (1952). On the structure of floral nectaries. Botanical Gazette 113: 464-470. 
24. Fahn, A. (1988). Secretory tissues in vascular plants. New Phytologist 108: 229-257.

25. Faraday, C.D. and, Thomson, W.W. (1986a). Structural aspects of the salt glands of the Plumbaginaceae. Journal of Experimental Botany 37: 461-470.

26. Faraday, C.D. and, Thomson, W.W. (1986b). Functional aspects of the salt glands of the Plumbaginaceae. Journal of Experimental Botany 37: 1129-1135.

27. Ferrero V, de Vega C, Stafford GI, Van Staden J, Johnson SD (2009). Heterostyly and pollinators in Plumbago auriculata (Plumbaginaceae). South African Journal of Botany 10: 1-7.

28. Foden, W. and Potter, L. (2015). Plumbago auriculata Lam, National assessment: Red List of Southern African Plants version 2015.1. Accessed on 2017/02/20. Available from site: http//redlist.sanbi.org/species.php?species-3567-1

29. Galal, A.M., Raman, V., Avula, B., Wang, Y.B., Rumalla, C.S., Weerasooriya, A.D. and, Khan, I.A. (2012). Comparative study of three Plumbago L. species (Plumbaginaceae) by microscopy, UPLC-UV and HPTLC. Journal of National Medicine 67: 554-561.

30. Glen, H.F. (2002). Cultivated plants of Southern Africa. Jacana. Johannesburg. pp 225-233.

31. Gonzales, W.L., Negritto, M.A., Suórez, L.H. and, Gianoli, E. (2008). Induction of glandular and non-glandular trichomes by damage in leaves of Madia sativa under contrasting water regimes. Acta Oecologica. 33: 128-132.

32. Grigore, M.N. and Toma, C. (2016). Structure of salt glands of Plumbaginaceae. Rediscovering old findings of the $19^{\text {th }}$ century: 'Mettenius' or 'Licopoli' organs? Journal of Plant Development 23: 37-52.

33. Hasanuzzaman, M., Nahar, K., Alam, M.D.M., Bhowmik, P.C., Hossain, M.D.A., Rahman, M.M., Prasad, M.N.V., Ozturk, M. and. Fujita, M. (2014). Potential use of halophytes to remediate saline soils. Biomed Research International. 1-12.

34. International Carnivorous Plant Society (ICPS) (2008). Evolution- the Caryophyalles Carnivores. pp 1-11. Accessed on 2015/08/20. Available from site: http//www.carnivorousplants.org/cp/EvolutionCaryophyalles.php

35. Ittiyavirah, S.P. and Paul, A.S. (2016). Gastroprotective effect of plumbagin and ethanolic extract of plumbaginales in experimentally-induced ulcer. Journal of HerbMed Pharmacology 5: 92-98.

36. Jain, D.L., Baheti, A.M., Jain, S.R. and, Khandelwal, K.R. (2010). Use of medicinal plants among tribes in Satpuda region of Dhule and Jalgaon districts of Maharashtra- An ethnobotanical survey. Indian Journal of Traditional Knowledge 9: 152157.

37. Jackson, J.K., Higo, T., Hunter, W.L. and Burt, H.M. (2008). Topoisomerase inhibitors as anti-arthritic agents. Inflammatory Research 57: 126-134.

38. Jaisi, A. and Panichayupakaranant, P. (2017). Enhanced plumbagin production in Plumbago indica root cultures by Lalanine feeding and in situ adsorption. Plant Cell, Tissue and Organ Culture 129: 53-60.

39. Jeyachandran, R., Mahesh, A., Cindrella, L., Sudhakar, S and, Pazhanichamy, K. (2009). Antibacterial activity of plumbagin and root extracts of Plumbago zeylanica L. Acta Biologica Cracoviensia series Botanica 51: 17-22.

40. Jose, B., Dhanya, B.P., Silja, P.K., Krishnan, P.N. and, Satheeshkumar, K. (2014). Plumbago rosea L.- A Review on Tissue culture and pharmacological research. International Journal of Pharmaceutical Sciences Review and Research 25: 246-256.

41. Joy, P.P., Thomas, J., Mathew, S. and, Skaria, B.P. (1998). Medicinal Plants. Tropical Horticulture 2: 1-211.

42. Kamatou, G.P.P., Viljoen, A.M., Figueireido, A.C. and, Tiley, P.M. (2007). Trichomes, essential oil composition and biological activities of Salvia albicaulis Benth. and Salvia dolomica Codd. two species from the Cape Region of South Africa. South African Journal of Botany 73: 102-108.

43. Katsoulis, L.C., Veale, D.H. and, Havlik, I. (2000). The pharmacological action of Rhoicissus tridentata on isolated rat uterus and ileum. Phytotherapy Research 14: 460-462.

44. Kaya, A., Demirici, B. and, Baser, K.H.H. (2006). Micromorphology of glandular trichomes of Nepeta congesta Fisch. \& May. var. congesta (Lamiaceae) and chemical analysis of the essential oils. South African Journal of Botany 73: 29-34.

45. Kennedy, D.O. and Wightman, E.L. (2011). Herbal extracts and phytochemicals: Plant secondary metabolites and the enhancement of human brain function. American Society for Nutrition, Advances in Nutrition 2: 32-50.

46. Khan, N.M.F.U. and Hossain, M.D.S. (2015). Scopoletin and $\beta$-sitosterol glucoside from roots of Ipomoea digitata. Journal of Pharmacology and Phytochemistry 4: 5-7.

47. Kobayashi, H. (2008). Ion secretion via salt glands in Poaceae. Japanese Journal of Plant Science 2: 1-8.

48. Kubitzki, K. (1993). Plumbaginaceae: The families and genera of vascular plants Volume 2. Springer-Verlag, Berlin Heidelberg. pp 523-530.

49. Lakshmanan, G., Bupesh, G., Vignesh, A., Sathiyaseelan, A. and, Murugesan, K. (2016). Micropropagation and anticancer activity of methanolic extract of Plumbago auriculata Lam. International Journal of Advanced Biotechnology and Research 4: 2001-2011.

50. Lange, B.M. (2015). The evolution of plant secretory structures and emergence of terpenoid chemical diversity. Annual Review of Plant Biology 66: 139-159.

51. Luteyn, J.L. (1990). The Plumbaginaceae in the flora of the South Eastern United States. SIDA, Contributions to Botany 14: $169-178$.

52. Maclachlan, A.A. and Carlquist, S. (1992). Non- glandular trichomes of Californian and Hawaiian tarweeds: surface ultrastructure and its significance.. Journal of Systematic and Evolutionary Botany13: 487-498.

53. Madhavam, V., Kumar, B.H.P., Murali, A. and, Yoganarasimhan, S.N. (2009). Antifertility activity of Drosera burmannii. Pharmaceutical Biology 47: 128-131. 
54. Mallavadhani, U.V., Sahu, G. and, Muralidhar, J. (2002). Screening of Plumbago species for the Bio-active marker Plumbagin. Pharmaceutical Biology 7: 508-511.

55. McGaw, L.J. and Eloff, J.N. (2008). Ethnoveterinary use of Southern African plants and scientific evaluation of their medicinal properties. Journal of Ethnopharmacology. 1-16.

56. Muringani, B.N. and Makwikwi, T. (2017). Assessment of phytochemical content and antibacterial activity of Plumbago auriculata E.coli species isolated from water sources in Mthata Region Eastern Cape, South Africa.. EC Microbiology 5.2: 74-78.

57. Naidoo, Y. and, Naidoo, G. (1998). Sporobolus virginicus leaf salt glands: morphology and ultrastructure. South African Journal of Botany 64: 198-204.

58. Naidoo, Y. and, Heneidak, S. (2013). Morphological investigation of glandular hairs on Drosera capensis leaves with an ultrastructural study of the sessile glands. Botany 91: 234-241.

59. Omwenga, O.E. and, Paul, O.O. (2012). Antimicrobial evaluation of the methanol bark extracts of Plumbago dawei Rolfe, a local species used by the Samburu community, Wambu, Samburu district, Kenya for the treatment of diarrheal ailments. Malaysian Journal of Microbiology 8: 248-252.

60. Padhye, S., Dandawate, P., Yusufi, M., Ahmad, A. and, Sarkar, F.H. (2010). Perspectives on medicinal properties of plumbagin and its analogs. Medicinal Research Reviews 10: 1-28.

61. Panicker, S. and Haridasan, V.K. (2016). A glimpse on insect capturing glandular hairs of Plumbago zeylanica Linn. and Plumbago auriculata Lam. Journal of Experimental Biology 3: 75-79.

62. Patwardhan, R.B., Shinde, P.S., Chavan, K.R. and, Devale, A. (2015). Reversal of plastid encoded antibiotic resistance from nosocomial pathogens by using Plumbago auriculata root extracts. International Journal of Current Microbiology and Applied Sciences 2: 187-198

63. Paul, A.S., Islam, A. and, Yuvaraj, P. (2013). Anti-Helicobacter pylori and cytotoxic activity of detoxified root of Plumbago auriculata, Plumbago indica, Plumbago zeylanica. The Journal of Phytopharmacology 2: 4-8.

64. Payne, W.W. (1978). A glossary of Plant Hair Terminology. Brittonia 30: 239-255.

65. Perveen, A. and Qaiser, M. (2004). Pollen flora of Pakistan- XXXIX. Plumbaginaceae. Pakistan Journal of Botany 36: 221-227.

66. Plachno, B.J., Adamec, L., Lichtscheidl, I.K., Peroutka, M., Adlassnig, W. and, Vrba, J. (2006). Fluorescence labelling of phosphatase activity in digestive glands of carnivorous plants. Plant Biology 8: 813-820.

67. Poornima, G., Manasa, M., Rudrappa, D. and, Prashith, K.T.R. (2012). Medicinal Plants used by herbal healers in Narasipura and Manchale villages of Sagara Taluk,Karnataka, India. Science, Technology and Arts Research Journal 1: 1217.

68. Pourmorad, F., Hosseinimeh S.J. and, Shahabimajd, N. (2006). Antioxidant activity, phenol and flavonoid contents of some selected Iranian medicinal plants. African Journal of Biotechnology 5: 1142-1145.

69. Purger, J.J., Kletecki, E., Trocsanyi, B., Muzinic, J., Purger, D., Szeles, G.L. and, Lanszki, J. (2012). The common leadwort Plumbago europea L. as a natural trap for the wintering Goldcrests Regulus regulus: a case study from Adriatic Islands. Journal of Biological Research- Thessaloniki 17: 176-179.

70. Rajasekaran, A., Nataraj, P., Ranganathan, M. and, Bose, P. (2015). Green synthesis of silver nanoparticle with Plumbago capensis L. aqueous root extract and its antifungal activity. European Journal of Pharmaceutical and Medical Research 4: 296-304.

71. Ramalhete, C., Lopez, D., Mulhovo. S., Rosario, V.E. and, Ferreira, M.J.U. (2008). Antimalarial activity of some plants traditionally used in Mozambique. Workshop Plantas Medicinais e Fitoterapeuticas nos Tropicos 31: 1-9.

72. Renner, T. and, Specht, C.D. (2011). A sticky situation: assessing adaptations for plant carnivory in the caryophyllales by means of stochastic character mapping. International Journal of Plant Science 172: 889-901.

73. Rusydi, A., Talip, N., Latip, J., Rahman, R.A. and, Sharif, I. (2013). Morphology of trichomes in Pogostemon cablin Benth. (Lamiaceae). Australian Journal of Crop Science 7: 744-749.

74. Saeidnia, S., Manayi, A., Goharia, A.R. and, Abdollahi, M. (2014). The Story of Beta-sitosterol- A Review. European Journal of Medicinal Plants 4: 590-609.

75. Saha, D. and, Paul, S. (2012). Cytotoxic activity of methanolic extracts of Plumbago indica L. (Family: Plumbaginaceae). Asian Journal of Pharmaceutical Technology 2: 59-61.

76. Saha, D. and, Paul, S. (2014). Antibacterial activity of Plumbago indica L. Turkish Journal of Pharmaceutical Sciences 11: 217-222.

77. Sakai, W.S. (1974). Scanning electron microscopy and energy dispersive x-ray analysis of chalk secreting leaf glands of Plumbago capensis. American Journal of Botany 61: 94-99.

78. Salama, F.M., El- Naggar, S.M. and, Ramadan, T (1999). Salt glands of some halophytes in Egypt. Phyton 39: 91-105.

79. Salmaki, Y., Zarre, S., Jahmzad, Z. and, Brauchler, C. (2009). Trichome micromorphology of Iranian stachys (Lamiaceae) with emphasis on its systematic implication. Flora 204: 371-381.

80. Simpson, M.G. (2010). Plant systematics. 2nd edition. Academic Press. pp 309.

81. Stoltzfus, A., Suda, J., Kettering, R., Wolfe, A. and, Williams, S, (2002). Secretion of digestive enzymes in Plumbago. Proceedings: The $4^{\text {th }}$ International Carnivorous Plant Conference. 203-207.

82. Stone, E. and, King, A. (1997). “Know your plants...safe or poisonous?”. California Poison Control System. pp 1-11. 
83. Storey, R. and, Thomson, W.W. (1994). An x-ray microanalysis study of the salt glands and intracellular calcium crystals of Tamarix. Annals of Botany 73: 307-313.

84. Sumsakul, W., Plengsuriyakarn, T., Chaijaroenkul, W., Viyanant, V., Karbwang, J. and, Na-Bangchang, K.1. (2014). Antimalarial activity of plumbagin in vitro and in animal models. BMC Complimentary and Alternate Medicine 12: 14-25.

85. Sunil ,C.1., Duraipandiyan, V., Agastian, P. and, Ignacimuthu, S. (2012). Antidiabetic effect of plumbagin isolated from Plumbago zeylanica L. root and its effect on GLUT4 translocation in streptozotocin-induced diabetic rats. Food Chemistry and Toxicology 50: 4356-4363.

86. That, I., Orhan, M., Gunesoglu, C. and, Gunesoglu, S. (2012). The antibacterial activity of Plumbago europea L. extract on textile surface. Fitoterapia 78: 52-68.

87. Tharmaraj, R.J.J.M. and, Antonysamy, J.M. (2013). Studies on the inter-specific variation in the genus Plumbago (Plumbaginaceae) from South India using phytochemical analysis. Indo American Journal of Pharmaceutical Research 3: 3892-3902.

88. Tharmaraj, R.J.J.M. and, Antonysamy, J.M. (2015). Screening of bacterial activity of selected Plumbago species against bacterial pathogens. Journal of Microbial Experimentation 2: 1-7.

89. The Plant List (2017). A working list of all plant species: Plimbago. Accessed on 2017/03/13. Available from site: http://www.theplantlist.org/tpl1.1/search?q=Plumbago.

90. Thomas, V. (1991). Structural, functional and phylogenetic aspects of the colleter. Annals of Botany 68: $287-305$.

91. Thomson, W.W. (1975). The structure and function of salt glands . In: Plants in saline environment. eds. Poljakof-Mayber and J. Gale. Springer Berlin. pp 118-146.

92. Tyagi, R. and, Menghani, E. (2014). A review on Plumbago zeylanica: A compelling herb. International Journal of Pharma Sciences and Research 5: 119-126.

93. Wagner, G.J. (1991). Secreting glandular trichomes: More than just hairs. Plant Physiology 96: 675-679.

94. Weryszko-Chmielewska, E. and, Chernetskyy, M. (2005). Structure of trichomes from the surface of leaves of some species of Kalanchoe Adans. Acta Biologica Cracoviensia Series Botanica 47: 15-22.

95. Wilson, J. (1890). The mucilage and other glands of the Plumbaginaceae. Annals of Botany 4: $231-258$.

96. Zhang, Z., Zhou, W. and, Li, H. (2005). The role of GA, IAA and BAP in the regulation of in vitro shoot growth and microtuberization in potato. Acta Physiologiae Plantarum 27: 363-369. 